\title{
A Decade after the Tsunami: Preliminary Exploration Deposit Layer of Sediment at Coast Area of Kedah, Malaysia
}

\author{
(Sedekad Selepas Tsunami: Penerokaan Awal Lapisan Endapan Sedimen di Kawasan \\ Pantai Kedah, Malaysia)
}

Siti Habibah Shafiai*, Azuraien Japper@ Jaafar, Teh Hee Min \& Ahmad Hadi

Mohamed Rashid

\section{ABSTRACT}

Study on tsunami deposits is done after a decade of the incident happened at Kedah, Malaysia. This article discusses the characteristics, measurement and thickness of tsunami deposits. It also provides the latest remaining evidences of the tsunami incident including imbrication pattern of cobbles, types of coastal protection and plants at the affected area. Run-up heights and inundation distance were taken into account for field exploration and investigation. This study may provide opportunities to understand how remaining evidences of tsunami could be tracked and recorded.

Keywords: Tsunami; paleo-tsunami; sediment deposit; coastal plants

ABSTRAK

Kajian ke atas endapan tsunami dilakukan selepas satu dekad kejadian itu berlaku di Kedah, Malaysia. Artikel ini membincangkan ciri-ciri, ukuran dan ketebalan endapan tsunami. Artikel ini juga memberikan maklumat tentang peninggalan bukti terkini oleh insiden tsunami itu termasuklah corak sususan batu, jenis-jenis perlindungan pantai dan tumbuh-tumbuhan di kawasan yang terjejas. Ketinggian ombak dan jarak banjir telah diambil kira untuk penerokaan lapangan. Kajian ini boleh memberi peluang untuk memahami bagaimana peninggalan bukti-bukti tsunami boleh dikesan dan direkod.

Kata Kunci: Tsunami; paleo-tsunami; endapan sedimen; tumbuhan pantai

\section{INTRODUCTION}

Malaysia was affected by tsunami incident brought by the Indian Ocean earthquake on 26 December 2004. The incident had caused significant damage to property and infrastructure facilities such as roads, ports, residential homes and others. Severely affected area at that time was Penang and Kedah (Colbourne 2005). The incident has driven lot of researches about it in Malaysia (Ismail et al. 2012; Jahromi 2009; Jamaluddin et al. 2010; Koh et al. 2009a; Koh et al. 2009b; Master, 2014; Teh et al. 2009). In fact, at early years of the incident, the studies are much related to the tsunami impact assessment and tsunami warning (Aasen et al. 2007; Ismail et al. 2012; Koh et al., 2009b; Master 2014).

Notwithstanding the incident happened long time ago, information from deposits left by tsunami such as water depth and velocity of past inundations, times and recurrence intervals may reduce losses in the future (Rhodes et al. 2006). As a matter of fact, Paleo-tsunami research is still new in Malaysia. Today, the findings of remaining tsunami deposit layer are documented based on site exploration at one of the affected state called Kedah. The main purpose of studying the tsunami deposit at Kedah, Malaysia was to provide the latest information on the tsunami deposits layer measurement and also the remaining evidences of the tsunami incident.

Exploration on identifying tsunami deposits have been done in several locations in Kedah, Malaysia. It includes desk studies on run-up heights and inundation distance of the area. The process of study continues with gathering a better understanding of the real problems at the site. The evidences of tsunami and its deposits were identified and recorded.

A team of researchers involved are from the Universiti Teknologi PETRONAS (UTP), National Hydraulic Research Institute of Malaysia (NAHRIM) with collaboration of Ministry of Science, Technology and Innovation (MOSTI). The outcomes from the study provide a better understanding the characteristics of tsunami deposits layers at Kedah, Malaysia. In addition, it provides new information on the process of tracking the remaining evidences of tsunami incident. It is definitely beneficial to the government and the society in Malaysia. 


\section{METHODOLOGY}

An M 9.3 earthquake deformed the ocean floor $160 \mathrm{~km}$ off the northwest coast of the Indonesian Island of Sumatra. Coastal plains of Perlis, Kedah and part of Perak and outlying islands, Penang and Langkawi are the affected areas. Figure 1 shows the affected coast area of Malaysia.
The sites for field visits were selected based on several main criteria: (1) land cover (mangrove forests, wetlands, and coral reefs); (2) land use patterns and (3) Operation of land use and building regulations and human habitation and infrastructure (buildings, drainage, and roads). The sites selection must also fulfil other criteria such as minimal site clean-up and reconstruction. This site visits are only a first step. There are still gaps to be filled in the future. Table 1 shows the criteria in details.

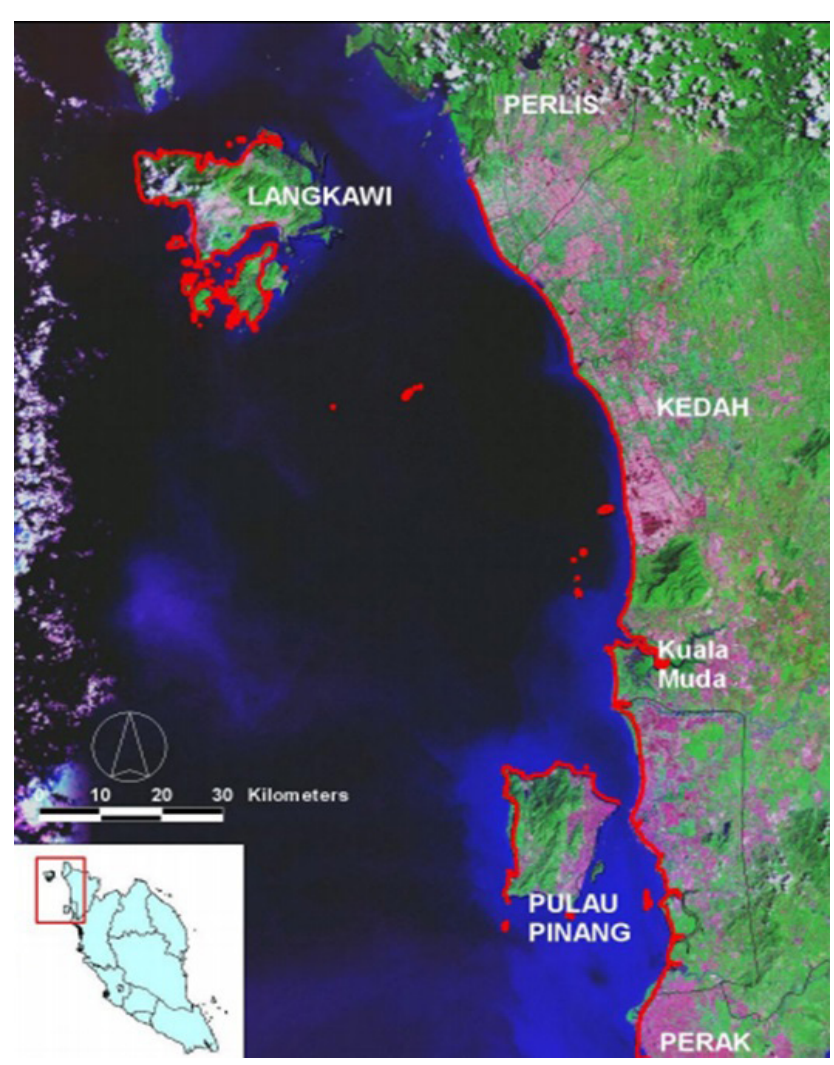

FIGURE 1. Tsunami's affected coastal area in Malaysia (Colbourne 2005)

\section{RUN-UP HEIGHTS AND INUNDATION DISTANCE}

According to Koh et al. 2009b, tsunami run-up heights along tsunami-impacted beaches in Peninsular Malaysia are varied between $2.3 \mathrm{~m}$ to $4.0 \mathrm{~m}$. Inundation distances recorded are varied from $13.4 \mathrm{~m}$ (Pantai Acheh, Penang) to $190 \mathrm{~m}$ (Tg. Tokong, Penang). There are some parts of Kedah have no record of inundation distance at all (Kuala Muda and Sg. Udang). Therefore, based on the run-up heights, inundation distances, minimal site clean-up and reconstruction, Kedah was chosen for site exploration. Penang and Perak of Malaysia were excluded because of the rapid development and the affected location difficult to access. Table 2 shows the detail coordinate of sites. Meanwhile, Figure 2-4 show the satellite view of the location, accordingly.

\section{IDENTIFICATION OF TSUNAMI AND PALEO-TSUNAMI DEPOSIT LAYER}

Field exploration for tsunami deposit was conducted from May 5 to May 7, 2015. Exploration tasks were divided into two categories: (1) to identify the remaining evidence of tsunami incident and (2) to measure the tsunami deposit layer.

The process of identifying the existing evidence of tsunami incident were based on suggested criteria by Peters and Jaffe (2010). Findings from the observation such as number of depositional layers, deposit thickness, deposit grading and etc. were observed and recorded.

Deposit layer was measured by excavating the selected locations from the top downwards. Spades and rectangular steel plate used as tools. 
TABLE 1. Desk Study Criteria

\begin{tabular}{|c|c|c|c|c|}
\hline Criteria & Description & Kampung Kuala Triang & $\begin{array}{l}\text { Kampung Hujung } \\
\text { Matang }\end{array}$ & Kampung Padang Salim \\
\hline \multirow[t]{2}{*}{$\begin{array}{l}\text { Land cover } \\
\text { (mangrove forests, } \\
\text { wetlands, and coral } \\
\text { reefs) }\end{array}$} & $\begin{array}{l}\text { Mangroves / wetland / } \\
\text { plants (Quantity over } \\
\text { the covered area/type } \\
\text { of plants) }\end{array}$ & $\begin{array}{l}\text {-Muddy beach } \\
\text {-Protected by only } \\
\text { scarce mangroves plant } \\
\text {-Some of the mangroves } \\
\text { were dead }\end{array}$ & $\begin{array}{l}\text {-Muddy beach } \\
\text {-Not protected by } \\
\text { mangroves/revetment }\end{array}$ & $\begin{array}{l}\text {-Muddy beach } \\
\text {-not protected by } \\
\text { mangroves/revetment }\end{array}$ \\
\hline & $\begin{array}{l}\text { Corals (Quantity over } \\
\text { the covered area) }\end{array}$ & No corals & No corals & No corals \\
\hline \multirow[t]{2}{*}{$\begin{array}{l}\text { Human habitation } \\
\text { and infrastructure } \\
\text { (buildings, } \\
\text { drainage, and } \\
\text { roads) }\end{array}$} & $\begin{array}{l}\text { Types of building } \\
\text { present at coastline }\end{array}$ & $\begin{array}{l}\text {-Tourism area, villages } \\
\text { and small businesses } \\
\text {-Self-made trench } \\
\text {-No systematic drainage } \\
\text {-Proper one is badly } \\
\text { maintained }\end{array}$ & $\begin{array}{l}\text {-Villages and small } \\
\text { businesses } \\
\text {-Small drainage from } \\
\text { village houses to the sea } \\
\text {-No industrial outlet }\end{array}$ & $\begin{array}{l}\text {-Villages and small } \\
\text { businesses } \\
\text {-Small drainage from } \\
\text { village houses to the sea } \\
\text {-No industrial outlet }\end{array}$ \\
\hline & $\begin{array}{l}\text { Rock / Boulder/ } \\
\text { Sandbanks (Size \& } \\
\text { shapes) }\end{array}$ & $\begin{array}{l}\text {-Rock revetment along } \\
\text { the coastline } \\
\text {-Sharp, medium and flat } \\
\text { rock } \\
\text {-Boulder being put } \\
\text { before tsunami occur }\end{array}$ & $\begin{array}{l}\text {-Rock revetment along } \\
\text { the coastline } \\
\text {-Sharp, medium and flat } \\
\text { rock } \\
\text {-Boulder being put } \\
\text { before tsunami occur }\end{array}$ & No rock revetment \\
\hline $\begin{array}{l}\text { Land use patterns } \\
\text { and the operation } \\
\text { of land use } \\
\text { and building } \\
\text { regulations }\end{array}$ & $\begin{array}{l}\text { Distance and height of } \\
\text { structure from shoreline } \\
\text { at full tide }\end{array}$ & $\begin{array}{l}\text {-No farm / plantation at } \\
\text { surveyed area }\end{array}$ & $\begin{array}{l}\text {-No farm / plantation at } \\
\text { surveyed area } \\
\text {-Village house very } \\
\text { close to the shore line, } \\
\text { as close } \\
\text { as }<30 \mathrm{~m}\end{array}$ & $\begin{array}{l}\text {-No farm / plantation at } \\
\text { surveyed area } \\
\text {-Village house very } \\
\text { close to the shore line, } \\
\text { as close } \\
\text { as }<30 \mathrm{~m}\end{array}$ \\
\hline
\end{tabular}

TABLE 2. Coordinate of sites

\begin{tabular}{|c|c|c|}
\hline Location & Point 1 coordinate & Point 2 coordinate \\
\hline Kampung Kuala Triang & $\begin{array}{l}\text { N6 }^{0} 21.674^{\prime} \text { (Latitude) } \\
\text { E99 } 42.766^{\prime} \text { (Longitude) }\end{array}$ & $\begin{array}{l}\text { N6 }{ }^{0} 21.669^{\prime} \text { (Latitude) } \\
\text { E99 } 42.767^{\prime} \text { (Longitude) }\end{array}$ \\
\hline Kampung Hujung Matang & $\begin{array}{l}\text { N5 } 5^{0} 35.180^{\prime} \text { (Latitude) } \\
\text { E100 } 20.360 \text { '(Longitude) }\end{array}$ & $\begin{array}{l}\mathrm{N} 5^{0} 35.185^{\prime} \text { (Latitude) } \\
\text { E100 } 20.347^{\prime} \text { '(Longitude) }\end{array}$ \\
\hline Kampung Padang Salim & $\begin{array}{l}\text { N5 }{ }^{0} 36.284^{\prime} \text { (Latitude) } \\
\text { E100 } 20.476^{\prime} \text { 'Longitude) }\end{array}$ & - \\
\hline
\end{tabular}

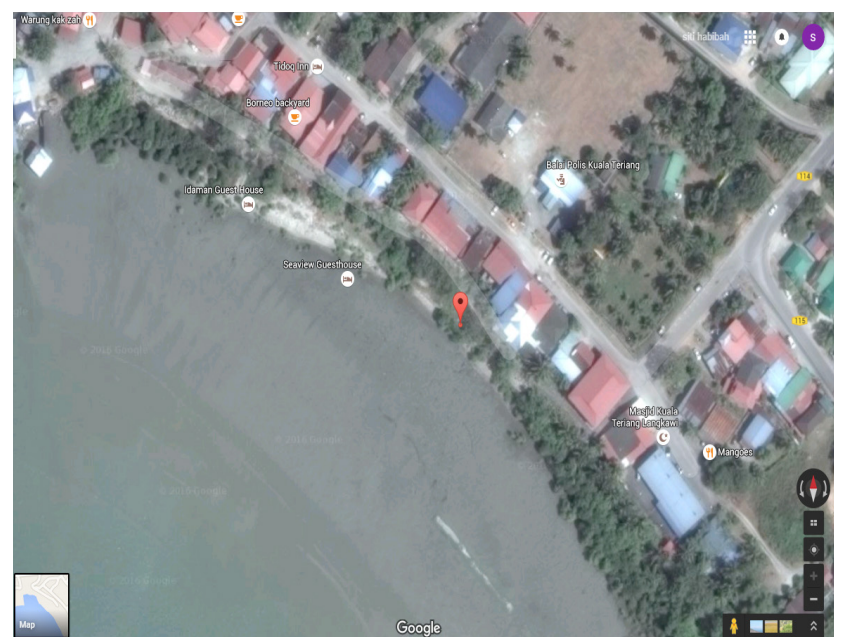

FIGURE 2. Kampung Kuala Triang Point 1 coordinate

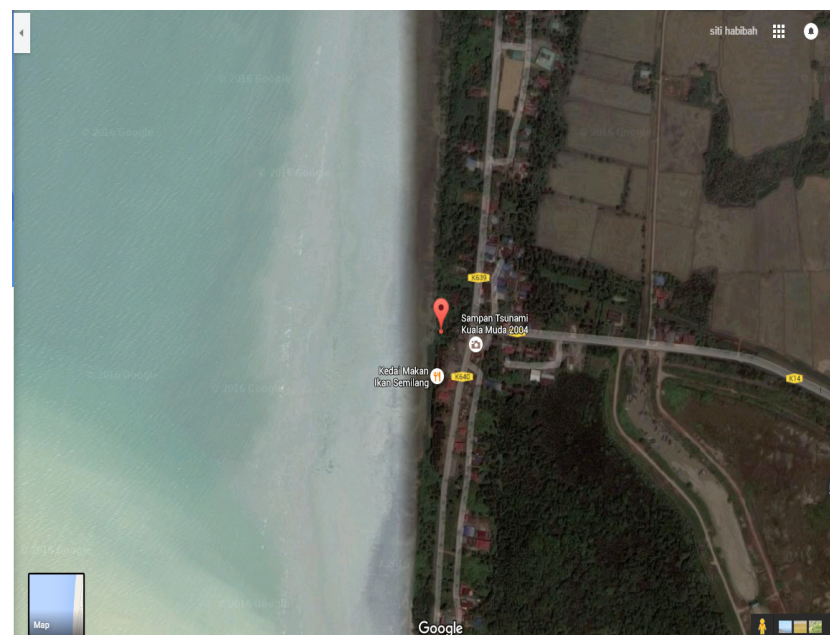

FIGURE 3. Kampung Hujung Matang Point 1 coordinate 


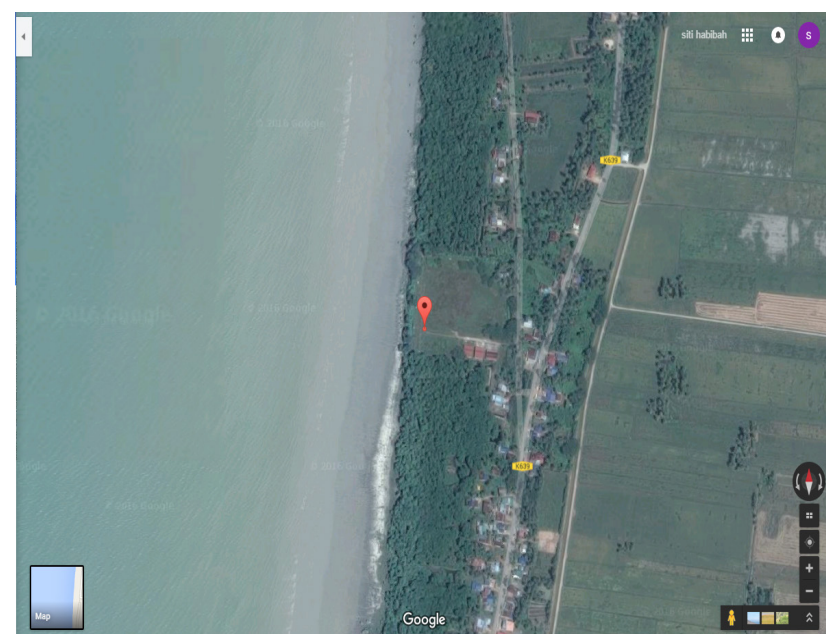

FIGURE 4. Kampung Padang Salim Point 1 coordinate

\section{RESULTS AND DISCUSSION}

Three (3) locations were observed and explored:

Kampung Kuala Triang, Kampung Hujung Matang and Kampung Padang Salim. Table 3 shows the findings.

\section{DEPOSIT LAYER}

The 2004 tsunami deposit in Kedah comprised mud and sand grains. In Kampung Kuala Triang (Point 1 and 2) and
Kampung Padang Salim (Point 1), the identification of the deposit was easy. The tsunami deposit and the underlying soil layer are sharp and contrast. The thickness of deposit layers were measured at each point locations. Figure 5 (a)(c) show the thickness of deposit at Kampung Kuala Triang and Kampung Padang Salim.

Meanwhile at Kampung Hujung Matang (Point 1 and 2 ), tsunami deposit layer was unable to be identified. The layers were unable to be seen as mud covered all over the digging surfaces. Figure 6(a) \& (b) show the situation.

In collecting the remaining evidence of the tsunami incident, there are several important findings that have been observed on the sites e.g. imbricated of cobbles, transported rocks, logs and vegetation at coastal area. A normal ocean wave could not transport rocks and logs easily. Those items might be transported from the sea and coastal line to the mainland by a high impact of wave of uprush tsunami. Sea shells are also found scattered and jumbled together with beach pebbles. Figure 7 shows the cobbles deposited near the shore were overlapping and angled by tsunami uprush. Figure 8(a)-(d) show the rocks, logs and sea shells transport.

Based on site observation, local eyewitness and local scientists' knowledge, vegetation grown healthily at affected land area. The uprush of tsunami sea water had re-mineralized the area. In fact, sea water contain natural elements of earth that are beneficial to vegetation (Majda 2014). Figure 9 (a-b) show the detail.

TABLE 3. Identification of tsunami incident

\begin{tabular}{cccc}
\hline Criteria (Peters \& Jaffe 2010) & Kampung Kuala Triang & Kampung Hujung Matang & Kampung Padang Salim \\
\hline $\begin{array}{c}\text { Sharp or erosional basal contact } \\
\text { The deposit geometry forms }\end{array}$ & YES & YES & NO \\
landward-thinning sand sheets & YES & YES & NO \\
Deposit thickness (Range 1-30 cm) & YES & YES & YES \\
Few depositional layers & NO. Only one single layer & NO. Only one single layer & NO. Only one single layer \\
observed & observed & YES \\
Normal grading & YES & YES & YES \\
Mud cap & YES & NO & Not Defined \\
Rip-up clasts & Not Defined & Not Defined & NO \\
Boulders & NO & YES & YES \\
Sedimentary structures & YES & YES & YES \\
\hline
\end{tabular}


(a)

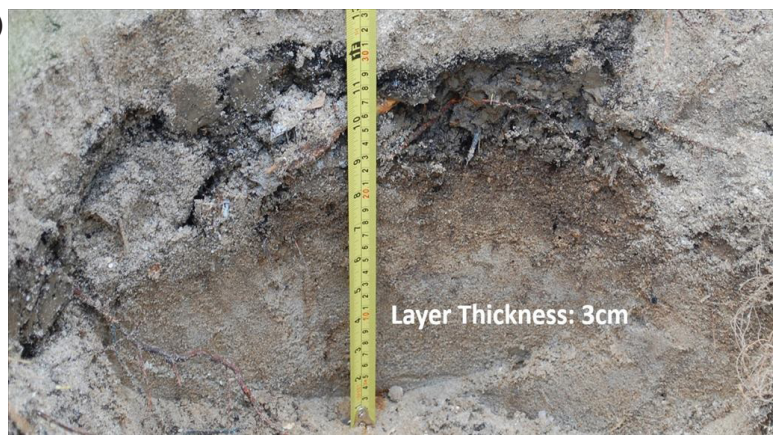

(b)

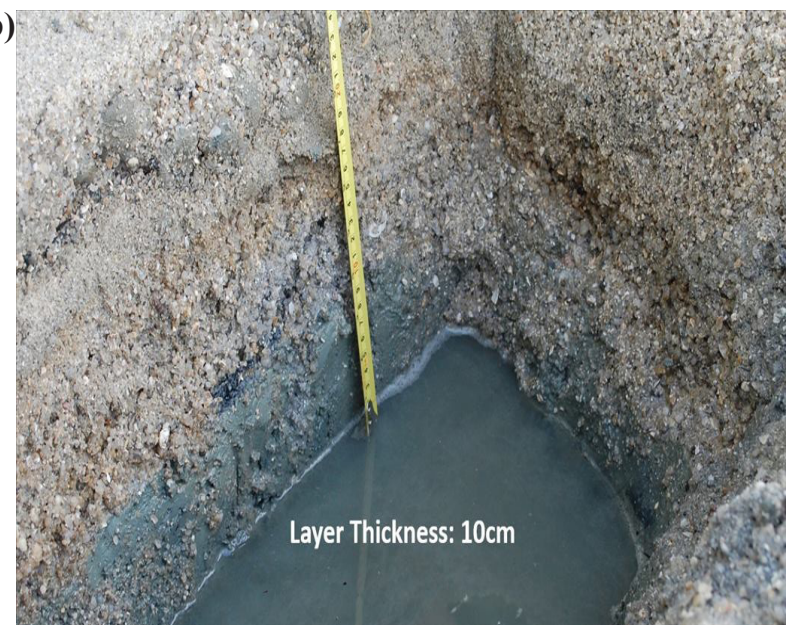

(c)

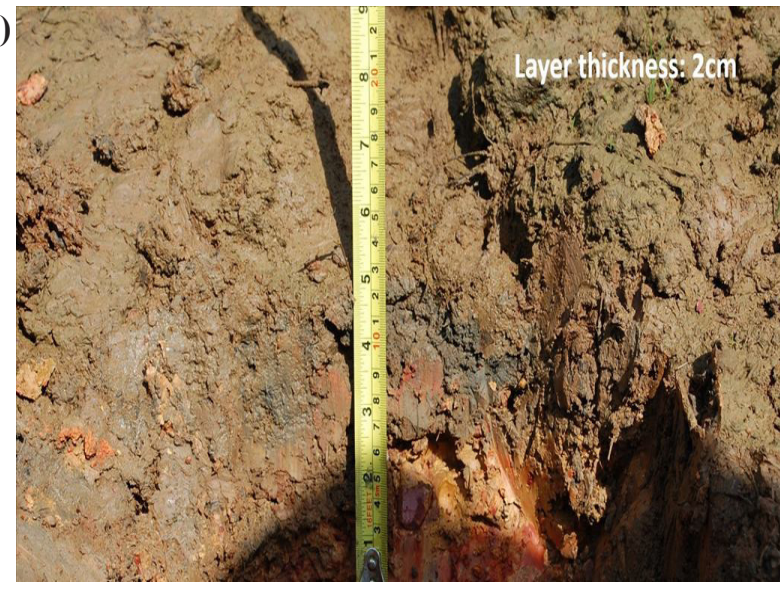

FIGURE 5. (a) The thickness of deposit layer at Point 1 Kampung Kuala Triang; (b) The thickness of tsunami layer at Point 2 Kampung Kuala Triang; (c) The thickness of tsunami layer at Point 1 Kampung Padang Salim
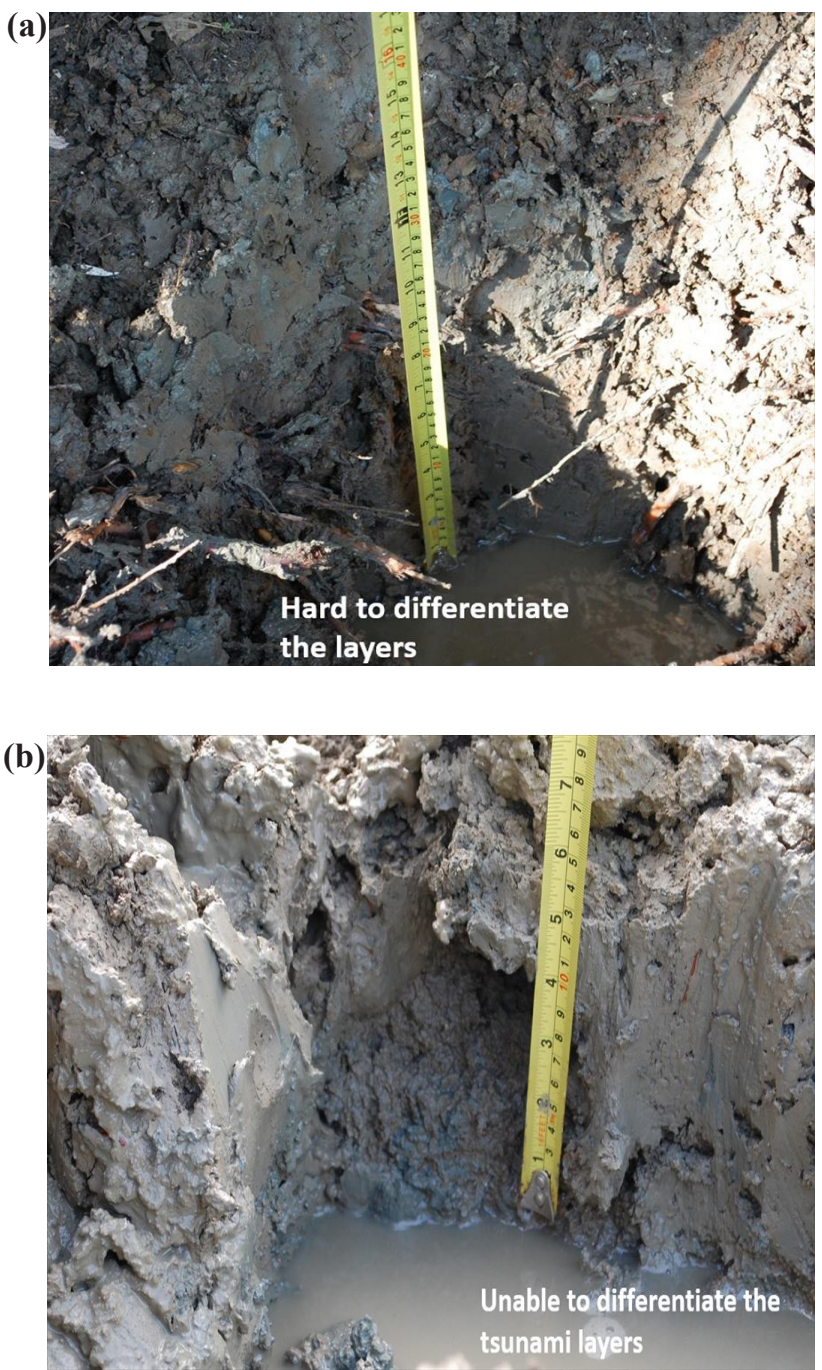

FIGURE 6. (a) Unidentified thickness of tsunami layer at Point

1 Kampung Hujung Matang and (b) Unidentified thickness of tsunami layer at Point 2 Kampung Hujung Matang 
(a)

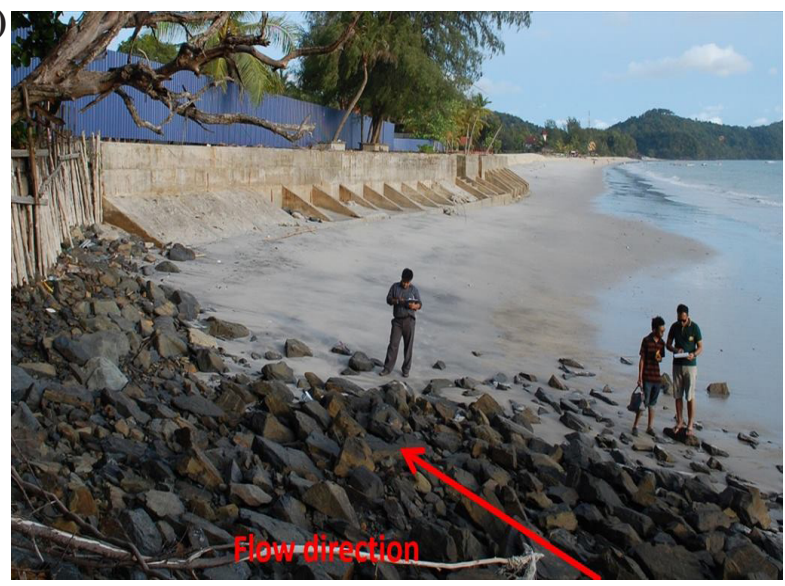

(b)

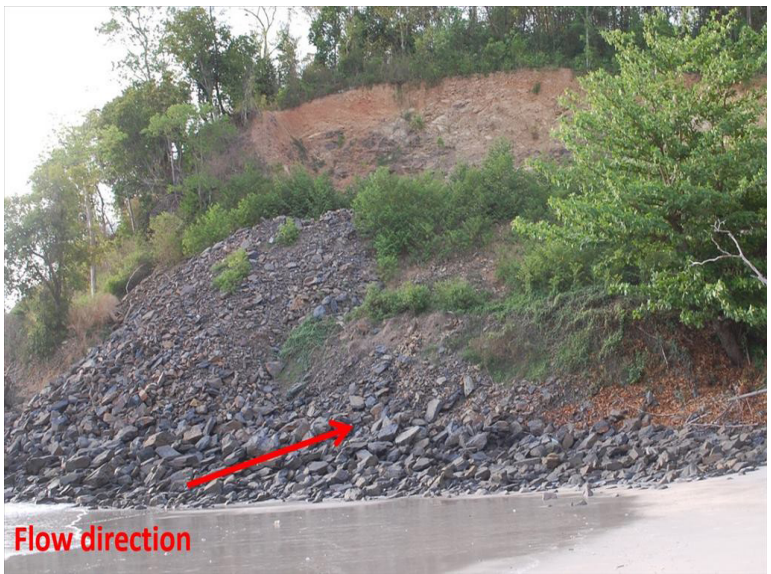

FIGURE 7. The imbricated cobbles by the tsunami uprush at Pantai Cenang

(a)

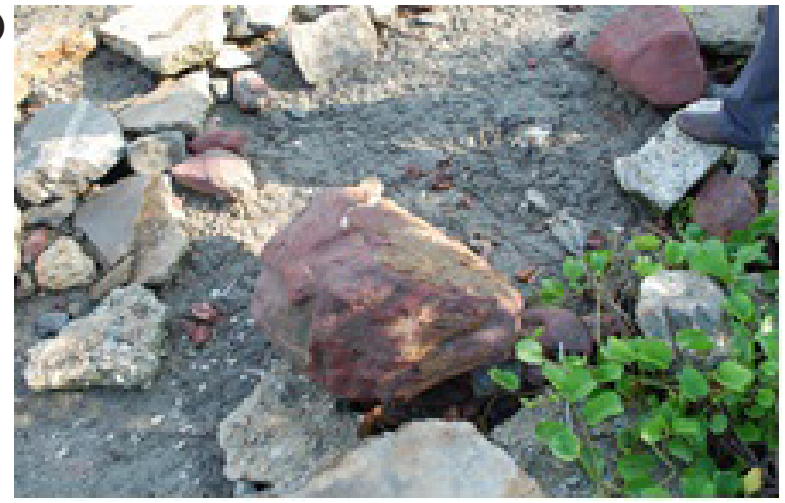

(c)

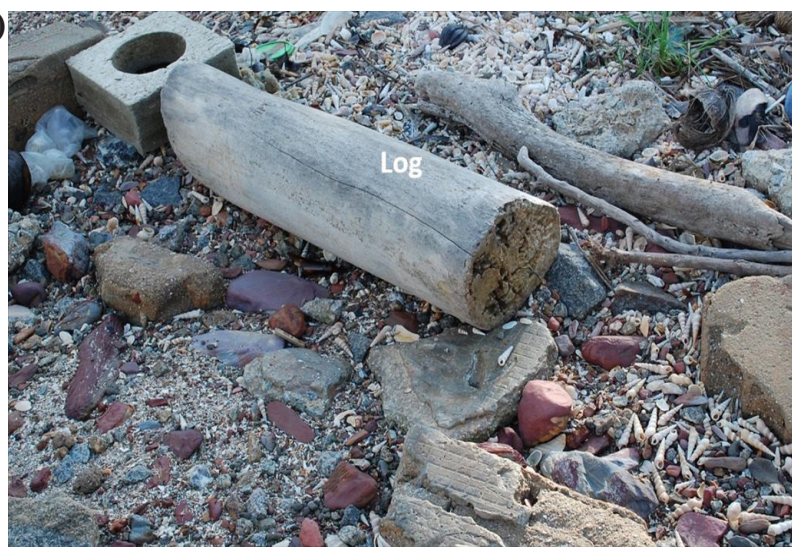

(b)

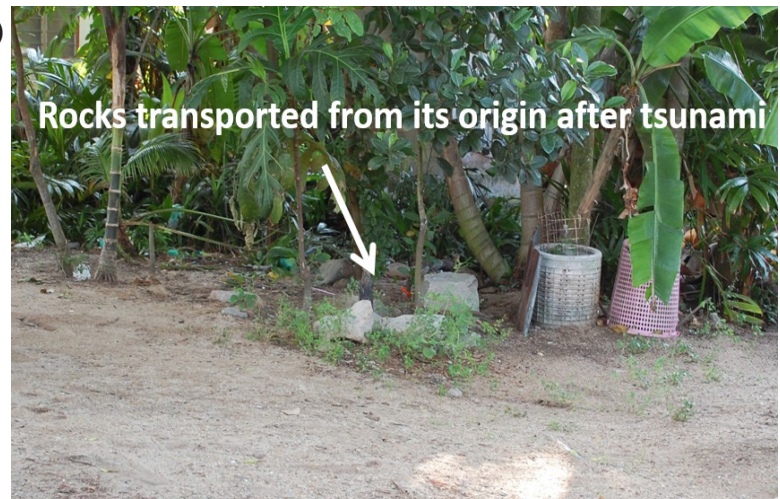

(d)

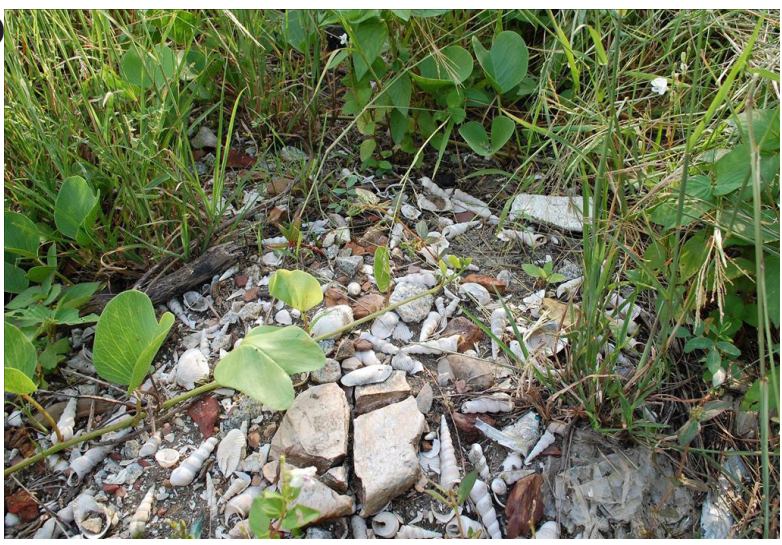

FIGURE 8. (a) Transported of rock at Kampung Hujung Matang, (b) The transported of rock at Kampung Kepala Jalan, (c) The transported logs at Kampung Hujung Matang and (d) Sea shells scattered at Kampung Hujung Matang 
(a)

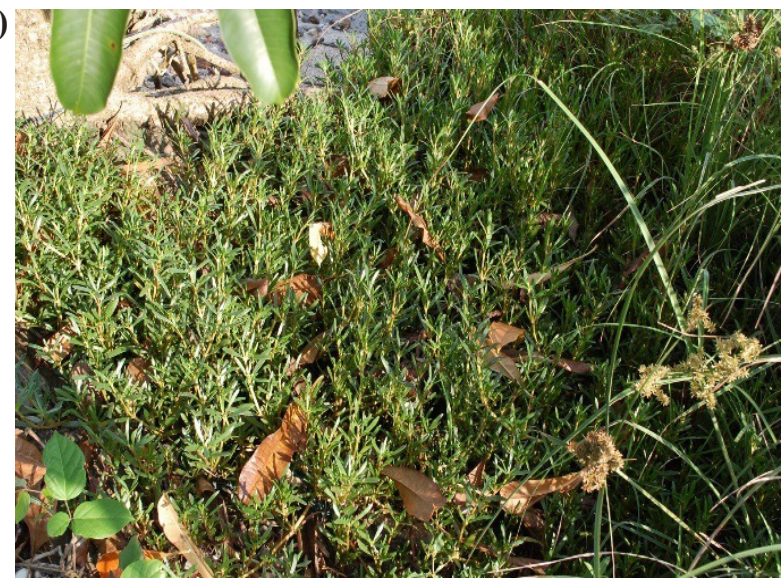

(b)

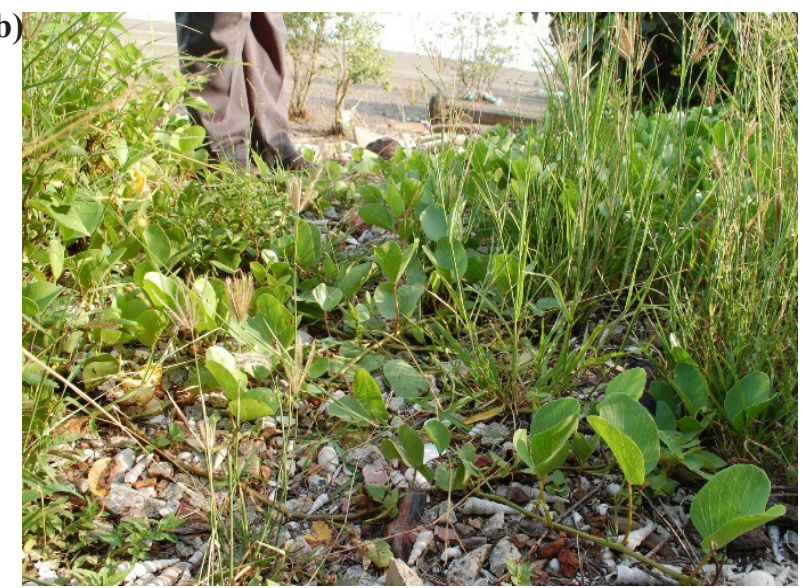

FIGURE 9. (a) Sesuvium portulacastrum and (b) Ipomoea and Elymus farctus (seagrass)

CONCLUSION

Tsunami deposits at selected locations of Kedah, Malaysia were successfully identified and measured. At Kampung Padang Salim, the deposit layer has sharp contact with the underlying material. The mud layer is seen sandwiched between 2 laterite soil layers. Contradict findings of tsunami deposit layer at Kampung Kuala Triang, where the deposits are sand and also has sharp contact with the underlying material. The sand layer is seen sandwiched between 2 mud layers. Thickness of deposit layers were measured between the ranges of 1-15 cm. Despite at Kampung Hujung Matang, the thickness of tsunami layer was difficult to be identified. Vegetation species at the area were observed. The minerals that brought by the uprush of the tsunami sea water helped the growth of vegetation at the area. Nevertheless, to date, identification of tsunami deposits is still challenging and an extremely difficult task. It requires proper instrument and involve interdisciplinary field studies including coastal engineering, sedimentological and etc. Nevertheless, findings from current research will always be valuable for local scientist reference as well as tsunami database for Malaysian coastal region. In fact, the outcome of this preliminary site visits are only a first step. There are still gaps to be filled in the future.

\section{ACKNOWLEDGEMENTS}

This research was fully supported by Ministry of Science, Technology and Innovation, Malaysia. We also thank our colleagues from Universiti Kuala Lumpur, Universiti Teknologi PETRONAS, and National Hydraulic Research Institute of Malaysia who provided insight and expertise that greatly assisted the research.
REFERENCES

Aasen, S., Mustapha, Z., Schjølberg, P., \& Elliott, T. 2007. A deepwater tsunami surveillance system for Malaysia. Paper presented at the Underwater Technology and Workshop on Scientific Use of Submarine Cables and Related Technologies, 2007. Symposium on.

Colbourne, F. 2005. Tsunami impact on the West Coast of Penang Island, Malaysia. Research Project Report, MS in Physical Sciences, Emporia State University, Emporia, Kansas, USA.

Ismail, H., Wahab, A. A., Amin, M. M., Yunus, M. M., \& Sidek, F. J. 2012. A 3-tier tsunami vulnerability assessment technique for the north-west coast of Peninsular Malaysia. Natural hazards 63(2): 549-573.

Jahromi, B. E. 2009. Design of a Tsunami Barrier to the North of Penang Island. Skudai: Universiti Teknologi Malaysia, Faculty of Civil Engineering.

Jamaluddin, T. A., Shuib, M. K., \& Mohd Amin, M. F. 2010. Tsunami 2004 and Palaeo-Tsunami Deposits in Malaysia. Petaling Jaya: National Technical Seminar on Earthquake \& Tsunami (NatSET 2010) JMM, Petaling Jaya, Selangor.

Koh, H. L., Teh, S. Y., Kew, L. M., \& Zakaria, N. A. 2009a. Simulation of future Andaman tsunami into Straits of Malacca by TUNA. Journal of Earthquake and Tsunami 3(02): 89-100.

Koh, H. L., Teh, S. Y., Liu, P. L. F., Ismail, A. I. M., \& Lee, H. L. 2009b. Simulation of Andaman 2004 tsunami for assessing impact on Malaysia. Journal of Asian Earth Sciences 36(1): 74-83.

Majda, W. 2014. Sea water and sea salt as organic fertilizer that makes healthy plants grow fast. http:// designerecosystems.com/2014/08/24/sea-water-andsea-salt-as-organic-fertilizer-that-makes-healthyplants-grow-fast/ 
Master, S. 2014. A Note on Imbricated Granite Boulders on NW Penang Island, Malaysia: Tsunami or Storm Origin? Tsunami Events and Lessons Learned (pp. 225-241): Springer.

Peters, R., \& Jaffe, B. 2010. Identification of tsunami deposits in the geologic record; developing criteria using recent tsunami deposits (2331-1258).

Rhodes, B., Tuttle, M., Horton, B., Doner, L., Kelsey, H., Nelson, A., \& Cisternas, M. 2006. Paleotsunami research. Eos, Transactions American Geophysical Union 87(21): 205-209.

Teh, S. Y., Koh, H. L., Liu, P. L. F., Ismail, A. I. M., \& Lee, H. L. 2009. Analytical and numerical simulation of tsunami mitigation by mangroves in Penang, Malaysia. Journal of Asian Earth Sciences 36(1): 38-46.

Siti Habibah Binti Shafiai* and Teh Hee Min

Civil \& Environmental Engineering Department,

Faculty of Engineering,

Universiti Teknologi PETRONAS,

32610 Bandar Seri Iskandar,

Perak Darul Ridzuan,Malaysia.
Azuraien Bt Japper@ Jaafar

Mechanical Department,

Faculty of Engineering,

Universiti Teknologi PETRONAS,

32610 Bandar Seri Iskandar,

Perak Darul Ridzuan, Malaysia.

Ahmad Hadi Bin Mohamed Rashid

Coastal and Oceanography Research Centre

National Hydraulic Research Institute of Malaysia, Seri Kembangan, Selangor, Malaysia

*Corresponding author; email: sitihabibah.shafiai@ petronas.com.my

Received Date: $23^{\text {rd }}$ December 2015

Accepted Date: $17^{\text {th }}$ March 2016 